\title{
Influence of irrigation on yield and quality of cv. Touriga Franca in the Douro Region
}

\author{
Inês Cabral $^{1}$, Tiago Nogueira ${ }^{2}$, Anabela Carneiro ${ }^{1,3}$ and Jorge Queiroz ${ }^{1,3}$ \\ ${ }^{1}$ DGAOT, Faculty of Sciences, University of Porto, Campus Agrário de Vairão, Portugal \\ ${ }^{2}$ Quinta do Crasto S.A., Gouvinhas, Sabrosa, Portugal \\ ${ }^{3}$ GreenUP/CITAB-UP, DGAOT, Faculty of Sciences, University of Porto, Campus Agrário de Vairão, Portugal
}

\begin{abstract}
The Douro Region is characterized by a typically Mediterranean climate, with extreme temperatures and irregular rainfall throughout the year. This experimental trial was carried out on a vineyard plot of Touriga Franca, grafted in 110R, at Quinta da Cabreira, property of Quinta do Crasto, S.A., located in the Douro Region. Four irrigation modalities were established, in three blocks, according to the percentage of cultural evapotranspiration (ETc): $\mathrm{R}_{0}$, the control, without irrigation; $\mathrm{R}_{25}$, irrigated with $25 \% \mathrm{ETc} ; \mathrm{R}_{50}$, with $50 \%$ ETc and $\mathrm{R}_{75}$, with $75 \%$ ETc. Irrigation had repercussions on total leaf area, with statistically significant lower value for $\mathrm{R}_{0}$ and greater for $\mathrm{R}_{75}$. Concerning the ecophysiological parameters, the water leaf potential was lower in $R_{0}$ than at $R_{50}$ and $R_{75}$. On the yield components, it was observed a higher number of clusters in $R_{75}$ and a smaller quantity in $R_{0}$ and the bunch weight was also affected by the amount of water provided, with the $\mathrm{R}_{50}$ or $\mathrm{R}_{75}$ having a higher value. Even if the berry weight has not presented differences, those factors affect yield, that was higher in the $\mathrm{R}_{50}$ and $\mathrm{R}_{75}$. Concerning the quality, no significant differences had been found on the various components tested.
\end{abstract}

\section{Introduction}

The vineyard in Portugal occupies a prominent place not only in terms of area - it is the third culture with the largest area in the country - but also because of its strong cultural and historical connection with the first Demarcated and Regulated region in the world (Douro), having an important socio-economic role.

Generically, the Douro Demarcated Region and in specific the Douro Superior Sub-region has some unique characteristics, either because of their soils and climate, being subject to strong water deficit during the Summer, motivated by low values of rainfall and high temperatures [1]. Despite this, the vine is a resistant plant and highly adapted to this type of conditions, having both anatomical and physiological characteristics that allow it to resist to stress conditions. Although these adaptive characteristics, in long drought periods some qualitative and quantitative changes might occur.

Nowadays, this problem is even more important due to the high inter-annual variability mainly justified by the climate change effect which brings new challenges for winegrowers [2].

The study of the irrigation effect on grape and wine quality and yield is an important problematic, although this practice is often considered a factor that has a negative influence on the quality of wines [3], persisting the idea that the water supply reduces the alcohol content and the phenolic extraction along with the increase of acidity [4].

In Portugal, until recently, irrigation was not practiced by winemakers because it was considered a derogatory factor, and it still has legal restrictions on its practice $[4,5]$. However, due to the intensification of drought and the consequent increase in water stress, producers have been adopting this procedure in order to increase production, in a way that this practice does not affect quality. The increase of the irrigated vineyard area, attests that using a rational irrigation system it is possible to increase the yield and eventually improve the potential quality of the musts. Nevertheless, it is a theme that requires a case-by-case study and adjustment according to the region, place, variety, soil, slope or climatic factors. Some of the challenges are to determine the quantity and timing of its application, the effect of irrigation and which are the best parameters for monitoring the water supply, relating them to the plant response to irrigation [6].

One of the methods used in vineyard irrigation and particularly in drip irrigation is the "Regulated Deficit Irrigation" (DRI) method, which establishes different levels of water restriction throughout the various stages of the vine cycle, thus using the plant evapotranspiration as a methodology for estimating the amount of water to be applied.

The present essay emerges as a way of testing different irrigation modalities at Quinta da Cabreira, in the Douro Superior Sub-region, near Vila Nova de Foz Côa, with the aim to test how different treatments can affect both quality parameters and yield in one of the most widespread grape variety in Portugal, Touriga Franca. 


\section{Materials and Methods}

\subsection{Characterization of the plot}

The trial was set up in 2015 (being presented in this paper the results of 2017), in a vineyard on a hillside with southern exposure. It had been selected three blocks, each one in a terrace with two rows. Each block was further divided into four irrigation modalities, corresponding each modality to twenty vines in each row, with data being collected in the central 10 vines. This way, the results of the trial had been collected in a total of 240 plants $(10$ vines $\times 2$ rows $\times 4$ irrigation modalities $\times 3$ blocks).

The vineyard was planted in 2007, grafted on 110 Richter, with a distance between plants of $1 \mathrm{~m} \times 2.2 \mathrm{~m}$. The training system is a vertical shoot positioned canopy, pruned in a single cordon Royat. The average altitude of the field trial was $240 \mathrm{~m}$ and the rows were oriented Northwest-Southwest.

Four irrigation modalities were tested: $\mathrm{R}_{0}$, the control treatment, which corresponds to non-irrigated vines; $\mathrm{R}_{25}$ corresponding to an irrigation of $25 \%$ of Cultural Evapotranspiration (ETc); $\mathrm{R}_{50}$ irrigated with $50 \%$ of ETc and $\mathrm{R}_{75}$ irrigated with $75 \%$ of ETc.

Water had been supplied six times, each 15 days, at night, in order to allow better soil water absorption and less evapotranspiration. It started in June $8^{\text {th }}$, according to the data provided by the probe existent in the plot and when the values of $\Psi_{\text {predawn }}$ fell below - 0.40 MPa.

\subsection{Field Determinations}

The foliar area was estimated using the model developed by Lopes \& Pinto [7]. One shoot of 2 plants per treatment was tagged in order to monitor the foliar area throughout the vegetative cycle. The data were collected on four different dates, corresponding to Baggiolini states of fruitset $(\mathrm{J})$, beginning of veraison $(\mathrm{M})$, maturity $(\mathrm{N})$ and harvesting $(\mathrm{N})$.

Point Quadrat, following the method of Smart and Robinson [8], was assessed during the veraison/maturity $(\mathrm{M} / \mathrm{N})$ and at harvest $(\mathrm{N})$ stages, at two different levels of canopy: at the vegetative and at the clusters level. Simultaneously, the exposed leaf area was also determined [9].

To estimate the evapotranspiration (ETc), the evapotranspiration values of the plant $\left(\mathrm{ET}_{0}\right)$ were collected from the meteorological station at Quinta da Cabreira and a value of Kc of 0.8 was selected having in account the period of irrigation and the characteristics of the soil $[4,10]$.

\subsection{Measurements of physiological activity}

The leaf water potential $\left(\Psi_{1}\right)$ was measured using a pressure chamber according to the methodology described by Scholander [11]. After irrigation began, $\Psi_{\text {predawn }}$ measurements were performed every morning before irrigation, every two weeks.

\subsection{Yield and fruit quality}

The maturity control began at August $3^{\text {th }}$. At harvest, 200 berries were collected per modality, in the exterior and interior row, in a total of 24 samples. The weight of the sample, the weight of the berry, the probable alcohol $(\%)$, the $\mathrm{pH}$, the total acidity $(\mathrm{g} / \mathrm{L})$, the anthocyanin $(\mathrm{mg} / \mathrm{L})$, polyphenols $(\mathrm{mg} / \mathrm{L})$ ) and malic acid $(\mathrm{g} / \mathrm{L})$ content were assessed.

The harvest was settled according to the results of the samplings carried out, as well as the weather forecast. At harvest the number of clusters and yield per plant were registered in the 20 vines selected per modality.

\subsection{Statistical Analysis}

The data throughout the trial were analyzed using the $\operatorname{SPSS}{ }^{\circledR}$ program version 23.0 , and subjected to analysis of variance (ANOVA). The parameters were recorded as non-significant, with the abbreviation "n.s." and significant with "*" for $\mathrm{p}<0.05, " * * "$ for $\mathrm{p}<0.01$ and "***" for $\mathrm{p}<0.001$. When the data analysis showed statistical significance, the means were compared using the least significant difference (LSD) test.

\section{Results and Discussion}

\subsection{Climatic characterization of the region}

Comparing with Climatic Normal (1931-1960) [12], the rainfall was generally lower for the agricultural year (from November 2016 to October 2017) particularly in the months of January, March, April, June, July, September and October, with values in average 50 to $60 \%$ inferior to the Normal $(534,9 \mathrm{~mm}$ for the reference period against $316,0 \mathrm{~mm}$ for the year of 2017).

The temperature values for the year of 2017 were higher $\left(16.5^{\circ} \mathrm{C}\right)$ when compared to Climate Normal $\left(16.1^{\circ} \mathrm{C}\right)$. That way, 2017 could be considered as an extremely hot and dry year [13].

\subsection{Fertility components}

The number of buds retained at winter pruning was of about $10 \mathrm{buds} / \mathrm{vine}$ and the percentage of budburst of about $96 \%$, with no differences between modalities. However, the fertility of the modality $\mathrm{R}_{0}$ (7.59 inflorescences/vine) was lower than the fertility of $R_{50}$ (9.19) and $R_{75}$ (9.37), presenting $R_{25}$ an intermediate value of 8.51 . The differences in fertility may have occurred due to accumulation of effect of irrigation provided in the previous years of 2015 and 2016.

\subsection{Characterization of the vegetation}

The results of the total leaf area, as shown in table 1, reflect an increase from the first to the second measurement, followed by a reduction on the next measurement in all modalities. As expected, $\mathrm{R}_{0}$ and $\mathrm{R}_{25}$ had both the lowest total leaf area, since basal leaf 
senescence (caused by lack of water) occurs over time. In fact, in the first measurement, performed on May $16^{\text {th }}$, the total leaf area was similar in the four modalities, decreasing then on the following measurements. At the end of maturation, the value for the non-irrigated modality $\mathrm{R}_{0}$, was less than half of the values of $R_{50}$ and $R_{75}$.

Table 1: Average Total Leaf Area $\left(\mathrm{m}^{2}\right)$.

\begin{tabular}{cccccc}
\hline $\begin{array}{c}\text { Modalities / day } \\
\text { of measurement }\end{array}$ & $\mathbf{R}_{\mathbf{0}}$ & $\mathbf{R}_{\mathbf{2 5}}$ & $\mathbf{R}_{\mathbf{5 0}}$ & $\mathbf{R}_{\mathbf{7 5}}$ & $\begin{array}{c}\text { Sig. } \\
(\mathbf{1})\end{array}$ \\
\hline May 16 & 2.08 & 1.81 & 1.98 & 2.27 & n.s. \\
June 7 & 3.29 & 3.12 & 3.75 & 4.25 & n.s. \\
July 20 & 3.27 & 2.66 & 3.49 & 3.56 & n.s. \\
September 9 & $\begin{array}{c}1.42 \\
\text { a }\end{array}$ & $\begin{array}{c}2.27 \\
\text { ab }\end{array}$ & $\begin{array}{c}2.84 \\
\text { b }\end{array}$ & $\begin{array}{c}\text { b } \\
\text { b }\end{array}$ & $* *$ \\
\hline
\end{tabular}

(1) Significance of the test ANOVA. "n.s." - not significant; “**” $-\mathrm{p}<0,01$.

The leaf layer number, presented in table 2, were similar in the first measurement on July $6^{\text {th }}$. However, in the measurement of September $9^{\text {th }}, R_{0}$ presented a value significantly smaller than $R_{75}$.

Table 2: Leaf Layer Number.

\begin{tabular}{|c|c|c|c|c|c|}
\hline $\begin{array}{c}\text { Modalities / } \\
\text { day of } \\
\text { measurement }\end{array}$ & $\mathbf{R}_{\mathbf{0}}$ & $\mathbf{R}_{25}$ & $\mathbf{R}_{\mathbf{5 0}}$ & $\mathbf{R}_{75}$ & $\underset{\text { (1) }}{\text { Sig. }}$ \\
\hline July 6 & 2.54 & 2.48 & 2.40 & 2.60 & n.s. \\
\hline September 9 & 1.48 & 1.98 & 2.52 & 2.65 & $*$ \\
\hline & $\mathrm{b}$ & $a b$ & $a b$ & $\mathrm{a}$ & \\
\hline
\end{tabular}

If the value observed for $\mathrm{R}_{0}$ is similar to those proposed by Smart and Robinson [8], this value is considered very low for Douro Region by Queiroz [14], having in mind the risk of sunburn. This risk can be also assessed by the percentage of external clusters (Table 3), that show an increase in the percentage of exposed clusters to the direct radiation of the sun on the $\mathrm{R}_{0}$ and $\mathrm{R}_{25}$ modalities.

Table 3: Percentage of Exposed Clusters.

\begin{tabular}{|c|c|c|c|c|}
\hline $\begin{array}{c}\text { Modalities / } \\
\text { day of } \\
\text { measurement }\end{array}$ & $\mathbf{R}_{\mathbf{0}}$ & $\mathbf{R}_{25}$ & $\mathbf{R}_{\mathbf{5 0}}$ & $\mathbf{R}_{75}$ \\
\hline July 6 & 22.54 & 5.56 & 30.56 & 12.96 \\
\hline September 9 & 58.33 & 45.93 & 5.56 & 15.00 \\
\hline
\end{tabular}

\subsection{Evapotranspiration and irrigation calculation}

The value of $\mathrm{Et}_{0}$ varies throughout the day and depends on several climatic factors, such as temperature, precipitation or wind speed.
According to the data of the meteorological station, as well as the volume of water to be applied and the flow rate of the drippers, it was possible to calculate the irrigation for each modality on the different days as shown in table 4 . The rainfall reported during the fifteen days before the first three irrigations, was deducted to the crop evapotranspiration value (ETc).

\subsection{Ecophysiological measurements}

\subsubsection{Predawn Water Potential}

Table 5 exhibits the values of $\Psi_{\text {predawn }}$ on the different days of measurement, measured in the night before irrigation. The values are similar in the first measurements, between May $25^{\text {th }}$ and July $20^{\text {th }}$, showing later disparities from the sixth measurement, corresponding to August $8^{\text {th }}$. Thus, although the irrigation started on June $8^{\text {th }}$, the differences between the modalities only became evident after August $8^{\text {th }}$, that is, two months later. These results may be related to the extremely dry and hot weather conditions that were observed throughout the grapevine cycle, posing us the question if the frequency irrigation of 15 days was adapted to the water supply of the plant.

Table 5: Predawn Water Potential (MPa).

\begin{tabular}{cccccc}
\hline $\begin{array}{c}\text { Modality / } \\
\text { Day }\end{array}$ & $\mathbf{R}_{\mathbf{0}}$ & $\mathbf{R}_{\mathbf{2 5}}$ & $\mathbf{R}_{\mathbf{5 0}}$ & $\mathbf{R}_{\mathbf{7 5}}$ & $\begin{array}{c}\text { Sig. } \\
(\mathbf{1})\end{array}$ \\
\hline May 25 & -0.33 & -0.35 & -0.37 & -0.34 & n.s. \\
June 8 & -0.36 & -0.43 & -0.40 & -0.40 & n.s. \\
June 23 & -0.41 & -0.37 & -0.40 & -0.38 & n.s. \\
July 7 & -0.50 & -0.49 & -0.50 & -0.48 & n.s. \\
July 21 & -0.57 & -0.53 & -0.50 & -056 & n.s. \\
August 9 & -0.82 & -0.71 & -0.63 & -0.52 & $*$ \\
& $\mathrm{a}$ & $\mathrm{ab}$ & $\mathrm{ab}$ & $\mathrm{b}$ & \\
August 18 & -1.05 & -0.81 & -0.88 & -0.76 & $* * *$ \\
& $\mathrm{a}$ & $\mathrm{bc}$ & $\mathrm{b}$ & $\mathrm{c}$ & \\
\hline
\end{tabular}

(1) Significance of the test ANOVA. "n.s." - not significant;
"** $-p<0,05 ;$;***” $-p<0,001$.

Over time, analysing table 5 , it can be noticed that there is a decrease in water potential in all modalities, reaching, according to Carbonneau [9], on August $18^{\text {th }}$ a severe level of stress, but with greater significance in the non-irrigated modality $\mathrm{R}_{0}$. It is also verified that the $\mathrm{R}_{75}$ 
4: Date of irrigation, Rainfall in the period $(\mathrm{mm}), \mathrm{ET}_{\mathrm{C}}, \mathrm{ET}_{0}$, Volume of water applied (L), Watering time $(\mathrm{m})$

\begin{tabular}{|c|c|c|c|c|c|c|c|c|}
\hline \multirow{2}{*}{$\begin{array}{l}\text { Irrigation } \\
\text { Number }\end{array}$} & \multirow{2}{*}{ Day } & \multirow{2}{*}{$\begin{array}{c}\text { Rainfall } \\
(\mathbf{m m})\end{array}$} & \multirow{2}{*}{$\begin{array}{c}\text { ETc } \\
(\mathbf{m m})\end{array}$} & \multirow{2}{*}{$\begin{array}{c}\mathbf{E T}_{0} \\
(\mathbf{m m})\end{array}$} & \multicolumn{3}{|c|}{ Volume of water applied (L) } & \multirow{2}{*}{$\begin{array}{l}\text { Watering } \\
\text { time (m) }\end{array}$} \\
\hline & & & & & $\mathbf{R}_{\mathbf{2 5}}$ & $\mathbf{R}_{\mathbf{5 0}}$ & $\mathbf{R}_{\mathbf{7 5}}$ & \\
\hline 1 & June 8 & 5,0 & 60,70 & 75,8 & 14,16 & 28,32 & 42,48 & $7 \mathrm{~h} 05$ \\
\hline 2 & June 23 & 3,8 & 73,20 & 91,5 & 17,54 & 35,08 & 52,62 & $8 \mathrm{~h} 46$ \\
\hline 3 & July 7 & 3,2 & 64,08 & 80,1 & 15,38 & 30,76 & 46,14 & $7 \mathrm{~h} 41$ \\
\hline 4 & July 21 & 0 & 75,04 & 93,8 & 18,76 & 37,52 & 56,28 & 9 h 23 \\
\hline 5 & August 9 & 0 & 73,20 & 91,5 & 18,30 & 36,60 & 54,90 & 9 h 09 \\
\hline 6 & August 18 & 0 & 69,68 & 87,1 & 17,42 & 34,84 & 52,26 & $8 \mathrm{~h} 43 \mathrm{~min}$ \\
\hline Total & & 11,0 & & & 101,56 & 203,12 & 304,68 & \\
\hline
\end{tabular}

modality, despite being also in severe stress is the one with the lowest base water potential.

\subsubsection{Daily Water Leaf Potential}

As shown in table 6 and as verified in other studies, the increase of both temperature and solar radiation, led to an increase in water losses due to transpiration, with a decrease in water leaf potential from early morning (10h) until mid-afternoon (14h). After this measurement there is a slight increase in these values, as verified by the late afternoon measurement (around 17h30) and then a noticeable recovery in the pre-dawn measurement.

Table 6: Daily Water Potential (MPa).

\begin{tabular}{|c|c|c|c|c|c|c|}
\hline Day & Hour & $\mathbf{R}_{\mathbf{0}}$ & $\mathbf{R}_{25}$ & $\mathbf{R}_{\mathbf{5 0}}$ & $\mathbf{R}_{75}$ & $\underset{\text { (1) }}{\text { Sig. }}$ \\
\hline Jul 7 & $\begin{array}{c}4 \mathrm{~h} \\
10 \mathrm{~h}\end{array}$ & $\begin{array}{c}-0.44 \\
a \\
-1.43 \\
a \\
\end{array}$ & $\begin{array}{c}-0.32 \\
b \\
-0.95 \\
b\end{array}$ & $\begin{array}{c}-0,28 \\
b c \\
-0.73 \\
c\end{array}$ & $\begin{array}{c}-0,24 \\
\mathrm{c} \\
-0.54 \\
\mathrm{~d} \\
\end{array}$ & $* * *$ \\
\hline \multirow{4}{*}{ Jul 21} & $4 h$ & $\begin{array}{c}-0.63 \\
a\end{array}$ & $\begin{array}{c}-0.53 \\
a b\end{array}$ & $\begin{array}{c}-0.44 \\
b\end{array}$ & $\begin{array}{c}-0.41 \\
b\end{array}$ & $* *$ \\
\hline & $10 \mathrm{~h}$ & $\begin{array}{c}-1.42 \\
a\end{array}$ & $\begin{array}{c}-1.23 \\
b\end{array}$ & $\begin{array}{c}-0.96 \\
b\end{array}$ & $\begin{array}{c}-0.79 \\
b\end{array}$ & $* * *$ \\
\hline & $14 \mathrm{~h}$ & $\begin{array}{c}-1.55 \\
a\end{array}$ & $\begin{array}{c}-1.38 \\
b\end{array}$ & $\begin{array}{c}-1.24 \\
b\end{array}$ & $\begin{array}{c}-1.00 \\
c\end{array}$ & $* * *$ \\
\hline & $17 \mathrm{~h} 30 \mathrm{~m}$ & $\begin{array}{c}-1.28 \\
\mathrm{a} \\
\end{array}$ & $\begin{array}{c}-0.79 \\
\mathrm{a} \\
\end{array}$ & $\begin{array}{c}-0.63 \\
b \\
\end{array}$ & $\begin{array}{c}-0.57 \\
b\end{array}$ & $* * *$ \\
\hline \multirow{4}{*}{$\begin{array}{c}\text { Aug 4- } \\
5\end{array}$} & $10 \mathrm{~h}$ & $\begin{array}{c}-1.32 \\
a\end{array}$ & $\begin{array}{c}-0.93 \\
b\end{array}$ & $\begin{array}{c}-0.68 \\
c\end{array}$ & $\begin{array}{c}-0.63 \\
c\end{array}$ & $* * *$ \\
\hline & $14 h$ & $\begin{array}{c}-1.50 \\
a\end{array}$ & $\begin{array}{c}-1.46 \\
a\end{array}$ & $\begin{array}{c}-1.40 \\
a\end{array}$ & $\begin{array}{c}-1.15 \\
b\end{array}$ & $* * *$ \\
\hline & $17 \mathrm{~h} 30 \mathrm{~m}$ & $\begin{array}{c}-1.49 \\
a\end{array}$ & $\begin{array}{c}-1.45 \\
a\end{array}$ & $\begin{array}{c}-1.41 \\
\mathrm{a}\end{array}$ & $\begin{array}{c}-1.14 \\
b\end{array}$ & $* *$ \\
\hline & $4 h$ & $\begin{array}{c}-0.68 \\
\mathrm{a} \\
\end{array}$ & $\begin{array}{c}-0.38 \\
\mathrm{~b} \\
\end{array}$ & $\begin{array}{c}-0.35 \\
b \\
\end{array}$ & $\begin{array}{c}-0.26 \\
b\end{array}$ & $* * *$ \\
\hline \multirow{4}{*}{$\begin{array}{c}\text { Aug } \\
\text { 18-19 }\end{array}$} & $10 \mathrm{~h}$ & $\begin{array}{c}-8.53 \\
a\end{array}$ & $\begin{array}{c}-5.23 \\
b\end{array}$ & $\begin{array}{c}-4.80 \\
b\end{array}$ & $\begin{array}{c}-4.68 \\
b\end{array}$ & $* * *$ \\
\hline & $14 h$ & $\begin{array}{c}-9.78 \\
a\end{array}$ & $\begin{array}{c}-8.35 \\
a b\end{array}$ & $\begin{array}{c}-7.23 \\
b\end{array}$ & $\begin{array}{c}-6.95 \\
b\end{array}$ & $* * *$ \\
\hline & $17 \mathrm{~h} 30 \mathrm{~m}$ & $\begin{array}{c}-9.33 \\
a\end{array}$ & $\begin{array}{c}-6.50 \\
b\end{array}$ & $\begin{array}{c}-6.05 \\
b\end{array}$ & $\begin{array}{c}-5.58 \\
b\end{array}$ & $* * *$ \\
\hline & $4 h$ & $\begin{array}{c}-6.10 \\
a\end{array}$ & $\begin{array}{c}-3.75 \\
b\end{array}$ & $\begin{array}{c}-3.25 \\
b c\end{array}$ & $\begin{array}{c}-2.80 \\
\mathrm{c}\end{array}$ & $* * *$ \\
\hline
\end{tabular}

There is a moderate to severe level of water stress in all modalities, which shows that this stress increases not only along the day but that is higher in the none irrigated or the less irrigated modalities. It is also verified that in the four measurements carried out, the differences between the modalities were statistically different, and it was also observed that, in general, the higher stress levels were in the non-irrigated modalities.

\subsection{Fruit quality and Yield}

\subsubsection{Quality}

Table 7 shows the evolution of the probable alcohol content (\%) in the different modalities, during the maturation period. It was observed that there is an increase along the maturation period, with final values that are considered high for this grape variety, but no differences between the treatments.

Table 7: Evolution of Probable Alcohol (\% v/v).

\begin{tabular}{cccc}
\hline $\begin{array}{c}\text { Day / } \\
\text { Modality }\end{array}$ & Aug 16 $^{\text {th }}$ & Aug 24 $^{\text {th }}$ & Sept 9 $^{\text {th }}$ \\
\hline $\mathbf{R}_{\mathbf{0}}$ & 11.80 & 13.60 & 14.68 \\
$\mathbf{R}_{\mathbf{2 5}}$ & 12.00 & 13.60 & 15.87 \\
$\mathbf{R}_{\mathbf{5 0}}$ & 11.90 & 13.70 & 15.23 \\
$\mathbf{R}_{\mathbf{7 5}}$ & 12.00 & 13.60 & 15.48 \\
Sig $^{(\mathbf{( 1 )}}$ & n.s. & n.s. & n.s. \\
\hline
\end{tabular}

(1) Significance of the test to Analysis of Variance of Means (ANOVA). "n.s." - not significant.

Although it was expected a dilution of sugar content in modalities with higher irrigation, this was not observed this year.

Table 8: Evolution of $\mathrm{pH}$.

\begin{tabular}{cccc}
\hline $\begin{array}{c}\text { Day / } \\
\text { Modality }\end{array}$ & Aug 16 $^{\text {th }}$ & Aug 24 $^{\text {th }}$ & Sept 9 \\
\hline $\mathbf{R}_{\mathbf{0}}$ & 3.92 & 3.86 & 4.19 \\
$\mathbf{R}_{\mathbf{2 5}}$ & 4.02 & 3.97 & 4.27 \\
$\mathbf{R}_{\mathbf{5 0}}$ & 4.01 & 3.90 & 4.22 \\
$\mathbf{R}_{\mathbf{7 5}}$ & 4.03 & 3.91 & 4.24 \\
Sig. $^{(\mathbf{1})}$ & n.s. & n.s. & n.s. \\
\hline
\end{tabular}


(1) Significance of the test ANOVA. "n.s." - not significant.

Regarding the $\mathrm{pH}$ values (Table 8), it was observed a reduction of this parameter from the first measurement to the second, and an increase in the third measurement, which corresponds to the harvest period.

All the treatments showed a similar behaviour and, in addition, it was verified that the increase is not constant between the different treatments. In the last measurement, the modalities that have a lower $\mathrm{pH}$ were $\mathrm{R}_{0}$ and $\mathrm{R}_{50}$. Nevertheless, all the modalities presented very high values of $\mathrm{pH}$.

Concerning the titrable acidity there were also no statistically differences between the modalities, as shown in table 9.

Table 9: Evolution of Titrable Acidity (g/L of Tartaric Acid).

\begin{tabular}{cccc}
\hline $\begin{array}{c}\text { Day / } \\
\text { Modality }\end{array}$ & Aug 16 $^{\text {th }}$ & Aug 24 & Sept $\mathbf{9}^{\text {th }}$ \\
\hline $\mathbf{R}_{\mathbf{0}}$ & 3.50 & 4.23 & 4.56 \\
$\mathbf{R}_{\mathbf{2 5}}$ & 3.72 & 4.34 & 4.24 \\
$\mathbf{R}_{\mathbf{5 0}}$ & 3.68 & 4.17 & 4.60 \\
$\mathbf{R}_{\mathbf{7 5}}$ & 3.81 & 4.19 & 5.44 \\
Sig $^{(\mathbf{1})}$ & n.s. & n.s. & n.s. \\
\hline
\end{tabular}

(1) Significance of the test ANOVA. "n.s." - not significant.

It was noted, however, that in all the treatments there was an increase of this parameter which was not expected.

Malic acid has generally a higher concentration at the beginning of maturation. The data in table 10 notice a decrease in all modalities over time, being this decrease more marked between the first and second measurements. Still, there was no evident relationship between the malic acid content ( $\mathrm{g} / \mathrm{L}$ ) and the irrigation level. Despite the non-statistically significant differences, the $\mathrm{R}_{0}$ and $\mathrm{R}_{50}$ values were lower than the remaining.

Table 10: Evolution of Malic Acid (g/L)

\begin{tabular}{cccc}
\hline $\begin{array}{c}\text { Day / } \\
\text { Modality }\end{array}$ & Aug 16 $^{\text {th }}$ & Aug 24 $^{\text {th }}$ & Sept 9 \\
\hline $\mathbf{R}_{\mathbf{0}}$ & 2.12 & 1.57 & 1.54 \\
$\mathbf{R}_{\mathbf{2 5}}$ & 2.45 & 1.93 & 1.91 \\
$\mathbf{R}_{\mathbf{5 0}}$ & 2.15 & 1.66 & 1.62 \\
$\mathbf{R}_{\mathbf{7 5}}$ & 2.40 & 1.73 & 1.73 \\
Sig $^{(\mathbf{1})}$ & n.s. & n.s. & n.s. \\
\hline
\end{tabular}

(1) Significance of the test ANOVA. "n.s." - not significant.

Observing the anthocyanins, there is a decrease in their values in all modalities, being most evident in the measurements from August $16^{\text {th }}$ to $24^{\text {th }}$, but also recorded from August $24^{\text {th }}$ to September $9^{\text {th }}$. There is also a higher anthocyanin content, although the values were not statistically significant, in the $R_{0}$ and $R_{50}$ modalities, the latter being the one that obtained the best results in the last measurement. This decreased was even more evident in the $\mathrm{R}_{0}$ and $\mathrm{R}_{75}$ modalities, as evidenced in table 11 .
Table 11: Evolution of Anthocyanins (mg/L).

\begin{tabular}{cccc}
\hline Day & Aug 16 & Aug 24 & Sept 9 \\
\hline $\mathbf{R}_{\mathbf{0}}$ & 336 & 158 & 146 \\
$\mathbf{R}_{\mathbf{2 5}}$ & 501 & 186 & 128 \\
$\mathbf{R}_{\mathbf{5 0}}$ & 421 & 158 & 150 \\
$\mathbf{R}_{\mathbf{7 5}}$ & 478 & 164 & 144 \\
Sig. $^{(1)}$ & n.s. & n.s. & n.s. \\
(1) Significance of the test ANOVA. "n.s." - not significant.
\end{tabular}

Water stress may have a beneficial effect on the synthesis of anthocyanins, but when pronounced, it will lead to a decrease in the photosynthetic activity and to the synthesis of sugars, thus negatively affecting the synthesis of colouring substances [4].

Another analysed component was the polyphenols content. From the analysis of table 12, a decrease of this compound is observed in all modalities. Due to a problem of the reagents used in this analysis, it was not possible to have the result from the modality $R_{75}$ modality on August $24^{\text {th }}$.

From August $24^{\text {th }}$ to September $9^{\text {th }}$ there is a statistically non-significant increase in the polyphenols content, with a concentration of this compound converging. It is observed a higher concentration of polyphenols in the modalities with higher irrigation supply, namely in $R_{50}$ and $R_{75}$. As in most of the previously analysed parameters, the $R_{50}$ modality was the one that exhibited a higher content of this constituent.

Table 12: Evolution of Polyphenols content (mg/L).

\begin{tabular}{cccc}
\hline $\begin{array}{c}\text { Day / } \\
\text { Modality }\end{array}$ & Aug 16 $^{\text {th }}$ & Aug 24 & Sept 9 $^{\text {th }}$ \\
\hline $\mathbf{R}_{\mathbf{0}}$ & 1392.2 & 572.9 & 836.4 \\
$\mathbf{R}_{\mathbf{2 5}}$ & 1803.7 & 583.9 & 822.2 \\
$\mathbf{R}_{\mathbf{5 0}}$ & 1795.8 & 259.7 & 877.8 \\
$\mathbf{R}_{\mathbf{7 5}}$ & 1741.4 & - & 865.7 \\
Sig $^{\cdot(\mathbf{1}}$ & n.s. & n.s. & n.s. \\
\hline
\end{tabular}

(T) Significance of the test ANOVA. "n.s." - not significant.

\subsubsection{Yield}

Regarding the clusters per vine (Table 13) there are statistically significant differences, particularly between the $R_{0}$ and $R_{75}$ modalities, which may, as referred, reflect the cumulative effect of irrigation, along the three years of study. Concerning the weight of the cluster, it was verified that, as expected, the water availability positively influenced the weight of the clusters, presenting $\mathrm{R}_{0}$ and $\mathrm{R}_{25}$ lower values than the more irrigated modalities $R_{50}$ and $R_{75}$. The berry weight, did not presented significant differences in any of the treatments.

In the analysis of the volume of the berries, as presented in table 13, a correlation between the weight of the berry and its volume is observed, as expected. Therefore, it is verified that the variations in weight are 
mainly due to the absorption of water or dehydration. It can be noticed that, although the differences were not significant between the modalities, the water availability could have contributed to the increase of the amount of pulp produced. In which case it was verified that the modalities $\mathrm{R}_{50}$ and $\mathrm{R}_{75}$, had higher values of berry weight, thus demonstrating a tendency to an increase of this parameter. On the other hand, the increase of the berry volume will lead to an increase in yield along with a decrease in the skin / pulp ratio.

Table 13: Number of clusters/vine, cluster weight $(\mathrm{g})$, berry weight $(\mathrm{g})$, volume of the berry $(\mathrm{mL})$ and yield/vine $(\mathrm{kg})$ registered at harvest.

\begin{tabular}{cccccc}
\hline Modality & $\mathbf{R}_{\mathbf{0}}$ & $\mathbf{R}_{\mathbf{2 5}}$ & $\mathbf{R}_{\mathbf{5 0}}$ & $\mathbf{R}_{\mathbf{7 5}}$ & Sig. ${ }^{\text {(1) }}$ \\
\hline $\mathbf{N}^{\mathbf{0}}$ clusters/vine & $7.60 \mathrm{a}$ & $8.80 \mathrm{ab}$ & $9.20 \mathrm{ab}$ & $9.27 \mathrm{~b}$ & $*$ \\
Cluster weight (g) & $150 \mathrm{a}$ & $172 \mathrm{ab}$ & $183 \mathrm{~b}$ & $179 \mathrm{~b}$ & $* *$ \\
Berry weight $(\mathbf{g})$ & 1.47 & 1.36 & 1.53 & 1.56 & n.s. \\
Berry volume (mL) & 0.94 & 0.82 & 1.04 & 1.09 & n.s. \\
Yield/vine (kg) & $1.21 \mathrm{a}$ & $1.60 \mathrm{ab}$ & $1.61 \mathrm{~b}$ & $1.71 \mathrm{~b}$ & $* *$ \\
\hline (1) Significance of the test to ANOVA. "n.s." - not significant; “*”- $<<0,05 ; “ * * ”-\mathrm{p}<0,01$.
\end{tabular}

Analysing the quality parameters, generally, no

At harvest, apart from counting the number of clusters per vine, they were also weighed. Table 13 shows the yield per modality. In this table, it can be noticed the correlation between the amount of irrigation to which the vines were subjected and the yield. The results show statistically significant differences between the non-irrigated mode and the two modalities with higher irrigation supply.

\section{Conclusions}

The results obtained in the present study allowed to draw some conclusions about the effect of irrigation. If the decision is to irrigate, the level of irrigation must be adequate according to the goals of the viticulturist.

Although this study is a follow-up of other studies carried out since 2015, the results obtained this year are very influenced by the climatic conditions data of the year. Thus, it appears to be a cumulative effect on the vines according to the amount of applied water since the beginning of the essay.

The results obtained show a strong influence of irrigation on the vegetative growth of vines, leading to canopies with higher leaf layer number and to a lower bunch exposure, and consequently to a reduced sunburn sensibility. Contrariwise, non-irrigated vines presented a lower foliar surface due to the basal leaves senescence, motivated by a strong hydric and thermal stress.

Regarding the ecophysiological measurements, namely the predawn leaf water potential, the values obtained showed that with 15 days between irrigations, all the modalities, including the more watered, present at end of the period a strong water deficit. In fact, after the first $7-8$ days all the vines presented visual signs of water stress, what was also confirmed by the values of the soil probe present in the plot. Therefore, it should be taken into account the hypothesis of irrigate more frequently. Thus, a weekly basis should be considered, so that the results could evidence the irrigation treatment instead of climatic factors. statistically significant differences between modalities

were found, namely alcohol, $\mathrm{pH}$ or phenolic composition.

Finally, in the yield components, the number of clusters was lower in $R_{0}$ than $R_{75}$, which can be interpreted as a cumulative effect of irrigation along the three years. Regarding the weight of clusters there were also differences between $\mathrm{R}_{0}$ and the two modalities with higher irrigation content. At harvest, there were statistically significant differences between the yield of the two treatments with the highest irrigation, when compared to the control treatment.

Being presented in this paper the results of the third year of the trial, it would important to continue this study, since the results showed large disparities among the three years, mainly because of the very different climatic conditions during this period.

\section{References}

[1] C. Almeida. História do Douro e do Vinho do Porto. Edições Afrontamento, 2006.

[2] G. Jones. Uma Avaliação do Clima para a Região Demarcada do Douro: Uma análise das condições climáticas do passado, presente e futuro para a produção de vinho. Vila Real, ADVID, 2013.

[3] A. Carbonneau, A. Deloire, B. Jaillard. La Vigne: Physiologie, terroir, culture. Paris: Dunod. 2007.

[4] N. Magalhães. Tratado de Viticultura - $A$ Videira, $A$ Vinha $e$ o "Terroir". Lisboa: Chaves FerreiraPublicações S.A. 2008.

[5] J.-L, Simon, J. Schwarzenbach, M. Mischler, W. Eggenberger, W. Koblet. Viticulture. Editions Payot Lausanne: Paris. 1978.

[6] B. Pilar, P. Sánchez-de-Miguel, A.Centeno, P. Junquera, R. Linares, J. Lissarrague. Water relations between leaf water potential, photosynthesis agronomic vine response as a tool for establishing thresholds in irrigation scheduling. Sci. Hortic., 114, 151-158. 2007. 
[7] C. Lopes, P. Pinto. Easy and accurate estimation of grapevine leaf area with simple mathematical models. Vitis, 44(2), 55-61. 2005.

[8] R. Smart, M. Robinson. Sunlight into wine - A handbook for winegrape canopy management (8th ed.). New Zealand: Winetitles. 1991.

[9] A. Carbonneau. General Relationship within the whole-plant: Examples of influence of vigour status, crop load and canopy exposure on the sink "berry maturation" for the grapevine. Proc. Workshop Strategies to Optimize Wine Grape Quality. Acta Hortic. 427, 99-118. 1996.

[10] T. Prichard, B. Hanson, L. Schwankl, P. Verdegal, R. Smith. Deficit Irrigation of Quality Winegrapes Using Micro-Irrigation Techniques. California: University of California Cooperative Extension. 2004.

[11] P. Scholander, E. Bradstreet, E. Hemmingson, H. Hammel. Sap Pressure In Vascular Plants: Negative Hydrostatic Pressure Can Be Measured In Plants. Science 148(3668), 339-46. 1965.

[12] IPMA. Normais Climatológicas - Classificação Climática de Koppen. IPMA. 2017.

[13] B. Teixeira, C. Val, C. Carlos, I. Gonçalves, A. Nave, S. Martins, F. Morais. Boletim 14-17 Ano Vitícola 2017 - Balanço Final. Vila Real: ADVID. 2017.

[14] J. Queiroz. Condução e Relações Rendimento Qualidade de Castas Nobres do Douro. Porto: Faculdade de Ciências, Secção Autónoma das Ciências Agrárias, Universidade do Porto. 2002. 